\title{
Das demandas monstruosas: as espectropoéticas de Günter Grass em Passo de caranguejo e Thomas Bernhard em Extinção: uma derrocada
}

\section{From the Monstrous Demands: The Spectropoetics of Günter Grass in Crabwalk and Thomas Bernhard in Extinction}

\section{Ravel Giordano Paz}

Universidade Estadual de Mato Grosso do Sul (UEMS), Campo Grande, Mato Grosso do Sul / Brasil

ravelgp@yahoo.com.br

Resumo: O artigo propõe uma aproximação contrastiva entre os romances Passo de caranguejo, do escritor alemão Günter Grass, e Extinção: uma derrocada, do austríaco Thomas Bernhard, explorando duas questões fundamentais em ambos: o tema da permanência do passado nazista em seus países de origem e os conluios e tensões entre as instâncias autorais e as vozes internas das narrativas. Com essa finalidade, e de modo a tentar expor as problemáticas ético-estéticas das obras em análise sem confiná-las a um ponto de vista judicativo, e sim sopesando seus impasses afectuais, buscamos orientar nossa discussão pela espectropoética do filósofo francês Jacques Derrida.

Palavras-chave: espectropoética; romance contemporâneo; literaturas de língua alemã; Günter Grass; Thomas Bernhard.

Abstract: The article proposes a contrastive approach between the novels Passo de caranguejo, by the German writer Günter Grass, and Extinção: uma derrocada, by the Austrian Thomas Bernhard, exploring two fundamental questions: the theme of the permanence of the Nazi past in their original nations and the collusions and tensions between the authorial instances and the internal voices of the narratives. With this purpose, and in order to try to expose the ethical-aesthetic issues of the works under analysis without confining them to a judgemental point of view, but rather by weighing their affectual impasses, we try to guide our discussion by the French philosopher Jacques Derrida's spectropoetics.

Keywords: spectropoetics; contemporary novel; German literature; Günter Grass; Thomas Bernhard. 
É preciso falar do fantasma, até mesmo ao fantasma e com ele, uma vez que nenhuma ética, nenhuma política, revolucionária ou não, parece possível, pensável e justa, sem reconhecer em seu princípio o respeito por esses outros que não estão mais ou por esses que ainda não estão aí, presentemente vivos, quer já estejam mortos, quer ainda não tenham nascido. ${ }^{1}$

\section{Introdução}

Evocar conjuntamente os nomes dos escritores Günter Grass e Thomas Bernhard constitui, por si só, o delineamento de uma problemática crítica. Para além do terreno em comum da língua alemã, a contemporaneidade geracional (Grass nasceu em 1927, Bernhard em 1931) e, sobretudo, a estreita relação com o contexto do pósguerra tornam as linhas gerais dessa problemática particularmente densas. Tanto a obra de Grass quanto a de Bernhard se estruturam, em larga medida, em torno de um tema que, em ambas, ganha contornos compreensivelmente obsessivos: as heranças e ressonâncias do nazismo na cultura, mentalidade e sensibilidade coletiva de seus países de origem, respectivamente a Alemanha e a Áustria. Os projetos literários de Grass e Bernhard apresentam-se, pode-se dizer, como formas de lidar com fantasmas, como depositários conscientes e cultivados de heranças e demandas monstruosas que se transfiguram em projeções e figurações espectrais. Algo, obviamente, que extrapola do ficcional para o biográfico, e vice-versa.

Daí a inegável cumplicidade, nessas obras, entre as instâncias autorais e determinadas figuras das diegeses narrativas. Mas o que torna essa prática singular nesses casos são as condições dramáticas em que ela se insere e, ao mesmo tempo, que ela encena: trata-se, afinal, de cumplicidades onde o próprio monstruoso avulta como um dado fundamental, o que implica, para além ou no âmago mesmo da problemática crítico-literária, em questões de fundo ético. Afinal, aqui, como na espectrologia ou espectropoética derridiana, é na forma de injunções inesquiváveis que as vozes espectrais - o espectro, insiste Derrida, é sempre um "mais de um"2 - se configuram. Mas como dar

\footnotetext{
${ }^{1}$ DERRIDA. Espectros de Marx: o estado da dívida, o trabalho do luto e a nova Internacional, p. 11.

${ }^{2}$ DERRIDA. Espectros de Marx: o estado da dívida, o trabalho do luto e a nova Internacional, p. 13.
} 
vazão a tais vozes - como falar, mais do que delas ou sobre elas, com elas, inclusive no sentido de ecoá-las em alguma medida, pois onde há espectros há contaminação e coabitação - quando o que elas portam é justamente o monstruoso, quando o que elas demandam é nada menos que a aniquilação do outro, a negação, eventualmente, do próprio direito ao advento do outro?

E é justamente nesse ponto crítico que, como veremos, Grass e Bernhard apontam para caminhos diferentes. Romances derradeiros e fulcrais nas trajetórias de seus autores, Passo de caranguejo e Extinção contêm muito - o primeiro por questões de ordem histórica e biográfica, e o segundo pela estética terminal anunciada no título - do que se costuma chamar de testamentos literários. O que apenas reforça a pertinência de inquiri-los em suas dimensões ético-estéticas, encetando um diálogo com as vozes espectrais em que eles próprios se constituem, no ágon e na tensa coabitação com as que os assombram.

\section{Passo de caranguejo: culpabilidade e demanda de inocência}

Publicado em 2002, Passo de caranguejo (Im Krebsgang) é o último romance de Günter Grass, e uma de suas últimas obras. Nele, o escritor alemão laureado com o Nobel de Literatura em 1999 reata um fio temático que desponta em seus primeiros livros, a trilogia constituída pelos romances $O$ tambor, Gato e rato e Anos de cão, respectivamente de 1959, 1961 e 1963: a presença e as consequências do nacional-socialismo na sociedade alemã. Ao mesmo tempo, Passo de caranguejo antecede uma polêmica que emergiria quatro anos depois, quando Grass revelou, no livro autobiográfico Nas peles da cebola, que não apenas aderira ao nazismo na juventude, o que já era conhecido, como fora membro, ao fim da guerra, da Schutzstaffel, ou SS, a tropa de elite hitlerista. Antecede e, de certa forma, antecipa, no sentido de que esse romance constitui a assunção de outra demanda antes apenas esboçada na trajetória do escritor: a de abordar frontalmente a questão do sofrimento da população alemã no período final do conflito mundial, particularmente num de seus episódios mais trágicos.

O mote a partir do qual se desenrola o enredo de Passo de caranguejo, e que se projeta como uma injunção ética e psicológica para o narrador (não exatamente protagonista, já que suas ações são escassas), é um episódio histórico pouco conhecido, ao menos fora da Alemanha, não obstante constitua nada menos que a maior tragédia 
marítima da História: no fim de janeiro de 1945, no auge da ofensiva aliada, o navio de cruzeiro alemão Wilhelm Gustloff, então convertido em navio-hospital, foi torpedeado por um submarino soviético enquanto transportava milhares de refugiados civis (além de um número bem menor de militares, o que possibilitou a não-classificação do evento como crime de guerra). Os números são imprecisos, mas estima-se que, de mais de 10.000 passageiros e tripulantes, apenas algumas centenas se salvaram.

E nesse cenário trágico que Grass insere a origem de seu narradorpersonagem fictício: o nascimento do jornalista Paul Pokriefke data justamente da hora mais trágica do evento real, quando milhares de pessoas, principalmente crianças, morriam afogadas e de hipotermia nas águas geladas do mar Báltico. Além disso, outros fatos históricos contribuem para tornar o personagem uma espécie de recipiente simbólico do trauma da experiência nazista: há exatos doze anos de seu nascimento, e, portanto, do dia em que o navio foi a pique, em 30 de janeiro de 1933, Hitler tomava o poder; e exatos 38 anos antes dessa data, em 30 de janeiro de 1895, nascia o "mártir" nacional-socialista Wilhelm Gustloff, líder do partido nazista suíço assassinado por um estudante judeu, e cujo nome, fechando o círculo sinistro de coincidências verídicas, batizou o navio afundado exatos 50 anos depois.

Esses fatos reais e ficcionais, porém, são apresentados na perspectiva temporal da narração, cujo presente é o final do século XX, quando outro drama fictício se desenrola. É nesse intercurso diacrônico - de certa forma ainda em curso, na medida em que o romance termina com uma interrogação acerca do futuro - que se enreda a teia de injunções espectrais em torno do narrador, e cuja principal artífice é sua mãe, Tulla Pokriefke. É ela quem, premida pelas lembranças traumáticas, exorta-o insistentemente a assumir a tarefa de narrá-las, municiando-o com as dolorosas memórias de seu percurso, grávida, até o navio, e do próprio naufrágio. Paul, no entanto, se esquiva o quanto pode a essa injunção, que acaba recaindo sobre seu filho adolescente, Konrad.

E é este, afinal, quem protagonizará a derradeira tragédia do romance. Criado pela avó, e afetado por suas demandas, Konrad aproximase da ideologia nazista e passa a cultivar a memória do "mártir" Wilhelm Gustloff, adotando seu nome, criando um website sobre ele e, finalmente, consumando um assassinato que constituiria uma vingança simbólica contra sua morte. A vítima, o jovem alemão Wolfgang Stremplin - um adversário virtual de Konrad -, culpabilizava-se pelas atrocidades do 
nazismo e adotara o nome do estudante judeu que executara Gustloff em 1936; situação, portanto, simetricamente inversa à do jovem Pokriefke.

Esses fatos pesam na consciência do narrador, que, por razões políticas e pessoais - sua indisposição com a mãe e a divisão da Alemanha no pós-guerra -, vira o filho crescer à distância, privando-o de uma interlocução que poderia fazer contraponto a Tulla. Além disso, em diversas situações Konrad vira-se tolhido ao tentar expor suas ideias e as demandas que as informam. Em tudo isso, Passo de caranguejo sustenta e ilustra ficcionalmente a tese de que a ausência de políticas de memória que contemplem as agruras vividas pelo povo alemão sob a égide do nazismo, ou que ao menos façam mais justiça à complexidade desse período de extremos, favorece a reemergência dos monstros do passado. Wilhelm Gustloff - assim o narrador o introduz no texto - é "alguém cujo túmulo foi destruído": 3 alguém a quem a memória e o trabalho de luto históricos foram negados, e cujo espírito, pode-se dizer, vaga inquieto pela Terra. Ao menos é assim que sente Konrad, que se apresenta como cabalmente movido por uma demanda de justiça. Por isso faz notar, em seu julgamento, que "Tal como eu, David Frankfurter atirou quatro vezes". ${ }^{4}$

Completa o quadro de personagens importantes o mais espectral deles: uma obscura figura referida apenas como "o Velho", e na qual não é difícil reconhecer, como faz Coetzee, ${ }^{5}$ um alter ego ou uma figuração interna de Grass; tanto que o narrador lhe atribui um livro, Anos de cão, do autor de Passo de caranguejo. ${ }^{6} \mathrm{O}$ cerne dessa relação, porém, é a própria injunção à qual o romance de 2002 atende: a escrita da tragédia do Wilhelm Gustloff por Paul Pokriefke honra um negócio firmado com o Velho, que o contratara para fazer o que ele mesmo não fora capaz.

É uma culpa que rói a consciência do Velho. Na verdade, diz ele, sua geração tinha a obrigação de registrar o sofrimento dos fugitivos da Prússia Oriental: os êxodos no inverno em direção oeste, a morte em dunas de neve, a agonia abjeta na beira da estrada em buracos de gelo [...]. Nunca, afirma ele, devíamos ter-nos calado sobre tanto

\footnotetext{
${ }^{3}$ GRASS. Passo de caranguejo, p. 9.

${ }^{4}$ GRASS. Passo de caranguejo, p. 179.

${ }^{5}$ COETZEE. Günter Grass e o Wilhelm Gustloff, p. 167.

${ }^{6}$ GRASS. Passo de caranguejo, p. 75.
} 
sofrimento, deixando esse tema proibido com as pessoas envolvidas com a direita, só porque nossa própria culpa era indiscutível e a confissão de arrependimento ficou em primeiro plano em todos aqueles anos. Uma omissão imperdoável...?

Vale notar que o próprio episódio do naufrágio é sutilmente lembrado em pelo menos outra obra de Grass: seu primeiro romance, O tambor, onde, a certa altura, o narrador-protagonista Oskar menciona a uma foto com um casal "na frente dos botes de salvamento do transatlântico Wilhelm Gustloff". ${ }^{8}$ Já no ulterior Gato e rato o navio não marca presença, numa narrativa, porém, repleta de embarcações, inclusive navios-hospitais, e onde o torpedeamento de navios militares e civis é um assunto recorrente. De fato, essa tragédia e seu entorno de acontecimentos pareciam assombrar o escritor, ainda que na forma de um fantasma sobrevoando ao longe.

Como um espectro ao mesmo tempo onipresente e intermitente, a voz do Velho pontua diversas passagens do romance, interrogando o narrador e orientando-o na tarefa que lhe delegou. $\mathrm{O}$ fato de o personagem - categoria que, nesse caso, talvez pedisse aspas - nem sempre ser nomeado, como na frase que abre o livro, reforça não só essa feição espectral como a vinculação com a instância autoral: "- Por que só agora? - perguntou alguém que não sou." Esse "alguém" ("jemand") 10 supostamente impreciso ressurge no final, instando o narrador a um novo "passo de caranguejo" em seu mergulho na dramática confluência de passado e presente que informa sua vida: "Poucos dias depois [de uma visita ao filho na cadeia de menores], ou melhor, no dia seguinte, alguém - ele, em cujo nome fui avançando em passo de caranguejo - me aconselhou a acessar a internet o quanto antes." Paul descobre, então, que o próprio Konrad começara a se tornar objeto de culto entre internautas, ganhando, como Gustloff, um site em sua homenagem. É

\footnotetext{
${ }^{7}$ GRASS. Passo de caranguejo, p. 96.

${ }^{8}$ GRASS. O tambor, p. 47. Especificamente a menção aos botes de salvamento parece uma alusão irônica ao naufrágio.

${ }^{9}$ GRASS. Passo de caranguejo, p. 7.

${ }^{10}$ GRASS. Im Krebsgang: Eine Novelle, p. 7, 216.
} 
quando advém o desabafo que encerra o livro: "Isso não vai acabar. Nunca isso vai acabar."11

Apresentando-se, ainda que de forma enviesada - mas o enviesamento, aqui, é estrutural -, como uma espécie de instrumento de outrem, Paul sublinha o caráter profundamente intrínseco a esse outro, "o Velho"/Günter Grass, das demandas que movem a escrita do romance. A metáfora do título, nesse sentido, refere-se não só à estrutura da narrativa - as idas e vindas dos entrechos histórico e ficcional, a aproximação gradual de seus respectivos clímax, etc. - como ao próprio drama autoral-escritural, aos atos e às esquivas de dizer e não dizer, de mostrar-se e esconder-se.

De um ponto de vista estritamente crítico-judicativo, haveria muito o que se apontar de problemático aí, com apoio, inclusive, na análise dos mecanismos literários. É possível demonstrar, por exemplo, como o derradeiro romance de Grass retoma um aspecto marcante da representação alegorizante de $O$ tambor - a saber, a recorrência a efeitos "espetaculares", em íntima e tensa relação com os códigos da cultura de massa e mesmo, ao menos no romance de 1959, com a estética do espetáculo do nazismo ${ }^{12}$ - em chave realista e atenuada, mas ainda assim fundamental. Os últimos passos da narrativa mesmo, como vimos, se consumam no apelo a um recurso típico das narrativas de suspense: a abertura para uma ameaça futura; e é curioso que a "deixa" para essa abertura se dê pela voz espectral do "alguém" cujo nome não declarado remete à instância autoral.

Mais ainda, a estética desviante de Passo de caranguejo se mostra suscetível a associações mais delicadas à luz das revelações autobiográficas de 2006: em que medida, por exemplo, os conluios autorais não são extensíveis à figura do jovem nazista Konrad Pokriefke? Assim como Paul ronda as verdades sombrias de seu filho, foi também

\footnotetext{
${ }^{11}$ GRASS. Passo de caranguejo, p. 205.

${ }^{12}$ Diversas e geralmente mórbidas situações "espetaculares" marcam a trajetória de Oskar, constituindo tanto um elemento temático - o personagem se integra a uma companhia circense a serviço do exército hitlerista - quanto um recurso narrativo. Em Passo de caranguejo, um rastro desse impulso espetacularizante está na própria exploração das simetrias e coincidências, de origem histórica, é verdade, mas que ele desdobra em outras.
} 
a árduos "passos de caranguejo", de alguém que ronda suas verdades íntimas mais dolorosas, que Grass afinal as trouxe à tona. ${ }^{13}$

Não sugerimos, obviamente, a permanência da cumplicidade com o nazismo. O próprio Konrad, num gesto simbólico ao fim do romance (e, também sugestivamente, à sombra de livros de Kafka), destrói com os punhos uma maquete do Wilhem Gustloff que ele mesmo construíra. Ainda assim, há aí, certamente, um complexo existencial-afectual que torna o próprio Grass, "o velho Grass", o personagem mais enigmático de sua obra. Um complexo onde culpabilidade e demanda de inocência ou perdão se entrelaçam num ágon entranhado, fadado a um círculo vicioso. E um andar de caranguejos, como se sabe, é também um andar em círculos.

Já em $O$ tambor se pode reconhecer a importância, senão centralidade, desse drama. Numa assombrosa farsa alegórica, acompanhamos a história de um grotesco personagem que decidiu parar de crescer; que desde sempre, portanto, põe em causa sua inocência mas ostenta, ao longo da vida, um esquivo e equívoco rastro dela: o próprio corpo infantil, mais tarde coroado com uma corcunda que é ao mesmo tempo a petição de inocência de um Quasímodo em sua quaseanimalidade e o peso da culpabilidade denegada. ${ }^{14}$ E não é difícil perceber como isso se transfigura, em outra chave, na construção de Konrad e seu entorno de espectros.

No entanto, do ponto de uma espectrologia, que é um ponto de vista crítico-afectual, o que cumpre sublinhar é como esse complexo comporta a possibilidade da própria fala: a possibilidade de dizer o quase

\footnotetext{
${ }^{13}$ Note-se, inclusive, a semelhança da metáfora da cebola sendo descascada com a do andar do caranguejo, enquanto forma tortuosa, com idas e vindas, para se chegar à verdade: "A cebola tem muitas peles. Elas existem em variedade. Mal está despelada, ela já se renova. Cortada, ela impele lágrimas aos olhos. Só ao ser despelada ela fala a verdade" (GRASS. Nas peles da cebola, p. 11).

14 Marcus V. Mazzari discute essa questão relacionando-a com a expressão "Graça do nascimento tardio", utilizada pelo chanceler alemão Helmut Kohl para sustentar que os alemães nascidos a partir de 1927 não poderiam ser responsabilizados pelas atrocidades do nazismo, pois não teriam condições de avaliá-lo criticamente. Grass nasceu justamente em 1927, e o nascimento de Oskar é localizado apenas três anos antes, em 1924. Cf. MAZZARI. Romance de formação em perspectiva histórica: $O$ tambor de lata de Günther Grass, p. 53.
} 
indizível, de abrir uma discussão dolorosa e necessária na qual se oferece a cara a tapa - ainda que na forma esquiva de um espectro com muitas caras.

\section{Extinção: injunções monstruosas e afetos impossíveis}

Também Extinção: uma derrocada (Auslöschung-Ein Zerfall), publicado em 1986, é o último romance e uma das últimas obras de seu autor, o austríaco Thomas Bernhard. Nele, o escritor retoma e, de certa forma, coroa, em sua narrativa mais extensa - na edição brasileira, com 475 páginas -, um tema recorrente na maioria das anteriores: a herança nacional-socialista na mentalidade e nos hábitos da população austríaca, sobretudo as elites rurais, não apenas no pós-guerra imediato como ao longo das décadas subsequentes.

Em Perturbação, de 1967, essa temática possuía um tratamento razoavelmente dinâmico, na medida em que se tratava do relato de um trajeto geográfico. Ao acompanhar o pai, um médico radicado no interior da Austria, em um dia de visitas profissionais, o narrador entra em contato direto ou indireto com uma série de personagens dos quais emanam diferentes tipos de perturbações psíquicas que terminam por afetar ao próprio jovem. Ainda assim, mais que a diversidade, pode-se dizer que a mesmidade é um elemento fulcral na narrativa: ao longo do trajeto, o narrador se depara com mais de um personagem cujos hábitos e ideias lembram muito os do derradeiro paciente visitado: o príncipe Saurau, proprietário do castelo Hochgobernitz. De certa forma, portanto, tudo converge para essa última e longa visita, na qual a amargura pela herança de uma Áustria devastada intelectual e espiritualmente pela complacência com o nazismo ganha toques de loucura. ${ }^{15}$

Extinção de certa forma radicaliza essa estrutura em abismo, na medida em que constitui a narrativa de um narrador-protagonista já prévia e intensamente afetado por heranças semelhantes, e que remói discursivamente sua vida pregressa, num acerto de contas com espectros vivos e mortos: é após o recebimento da notícia de que seus pais e seu irmão mais velho morreram em um acidente de carro que Franz-Joseph

${ }^{15}$ BERNHARD. Perturbação. Discutimos essa obra em outro estudo, abordando-a sob o prisma das poéticas do entusiasmo; no caso, um entusiasmo que se configura no cultivo dos paradoxos e da negatividade. Cf. PAZ. A invocação dos rancores: alieni(ili) smo e (in)transcendência na Perturbação de Thomas Bernhard. 
Murau se lança à empreitada de proceder a "extinção" discursiva de tudo o que habita sua existência. Nesse sentido, mais do que um narrador em primeira pessoa, Murau é uma espécie de filtro afetivo-espectral dos fatos narrados, de tal forma que seu discurso afeta constituir uma narrativa mais expressiva do que representacional.

E também aqui, como em Passo de caranguejo, é numa espécie de coabitação mútua entre a instância autoral e a diegese ficcional que a narrativa se inicia: na primeira oração, um breve aposto insere outra voz que não a do narrador na elocução deste, como se ambas fossem uma só: "Depois da conversa com meu aluno Gambetti, com quem no dia 29 me encontrei no Pincio para combinar as datas das aulas de maio, escreve Franz-Joseph Murau [...]."16

Essa voz, que podemos aproximar da do Velho no romance de Grass, retorna apenas na penúltima linha do romance, configurando assim uma espécie de moldura espectral numa obra onde as intersecções espectrais são, mais do que recorrentes, estruturais. Em primeiro lugar, porque a referida coabitação se confirma facilmente na leitura dos textos autobiográficos de Bernhard: não só o estilo hiperbólico como figuras e experiências reais encontram larga correspondência na ficção. ${ }^{17}$ Mas, além disso, há a verdadeira plêiade de relações presentes e passadas, mas sempre fortemente psíquicas, cuja exposição nutre o discurso do narrador, a começar pela que se estabelece com o personagem nomeado naquela abertura: seu aluno Gambetti, um jovem e rico italiano a quem ministra aulas particulares de literatura alemã, atividade à qual Murau se dedica por diletantismo e, no fim das contas, pelo vínculo afetivo, já que pertence a uma riquíssima família de proprietários rurais da Alta Austria, com rendas mais que suficientes, por exemplo, para alugar um apartamento extremamente caro em Roma, onde reside.

$\mathrm{Na}$ primeira parte do romance, a matéria narrativa consiste, em boa medida, na suposta transcrição - afetando uma exatidão que naturalmente é impossível verificar, mas que em todo caso compõe o

\footnotetext{
${ }^{16}$ BERNHARD. Extinção: Uma derrocada, p. 7.

${ }^{17}$ A leitura das narrativas autobiográficas do autor não deixa dúvidas quanto a esse trânsito. Os insultos que Bernhard narra ter ouvido da mãe, por exemplo, poderiam constar perfeitamente de Extinção. Cf. BERNHARD. Origem, p. 17-19. Cf., também, DÁVALOS. Ficção e autobiografia: uma análise comparativa das narrativas de Thomas Bernhard.
} 
quadro psicológico obsessivo do narrador - de diversas conversas entre Murau e Gambetti, e que, longe de se confinarem aos estudos contratados, giram em torno, sobretudo, das mazelas que o primeiro atribui a sua própria família e seu lugar de origem: Wolfsegg, uma vasta propriedade localizada numa região cuja paisagem ele descreve como magnífica, mas onde as relações seriam marcadas, sobretudo na própria Wolfsegg ${ }^{18}$ por aspectos profundamente perversos.

Essas transcrições são marcadas pela reiterada referência ao interlocutor, aliás, à própria interlocução, sobretudo por meio da expressão "[eu] disse a Gambetti" e variações ("dissera a Gambetti”, "dizia a Gambetti”, etc.), o que marca esse personagem com o qual não nos deparamos "presencialmente" em nenhum momento como um ponto de apoio e articulação inicial para as injunções do próprio narrador: a presença espectral de Gambetti é uma espécie de âncora à qual ele se agarra para não se deixar tragar pelo turbilhão de lembranças e amarguras familiares, e, ao mesmo tempo, para haver-se discursivamente com elas, quase ao modo de um trabalho psicanalítico, obviamente pouco ou nada eficaz, senão contraproducente, já que orientado apenas por seus rancores e vaidades. Assim, por um lado Murau "assombra" Gambetti com suas demandas, e, por outro, o retorno das mesmas em seu discurso atesta sua permanência reforçada.

Como já dissemos, o que cataliza o fluxo - talvez se possa dizer surto - escritural do narrador é o telegrama noticiando a morte de seus pais e seu irmão, o que obviamente indica uma situação traumática. No entanto, é apenas a contrapelo de tudo ou quase tudo que lemos, enquanto percepção de algo fundamente reprimido, que se pode -e, afinal, se deve - ler Extinção como uma espécie de trabalho de luto, ou seja, como um texto tecido, também, em consideração aos mortos.

Longe de se mostrar abalado, o que Murau sente - ou afirma ter sentido - ao se deparar com o telegrama noticiando a tragédia é angústia pela obrigação de retornar a Wolfsegg, de onde chegara há poucos dias. Como muitos tópicos que lhe advêm ao espírito - ou, em todo caso, àquilo de seu espírito que se plasma em sua escrita -, este é insistentemente

\footnotetext{
${ }^{18}$ Como no caso de Hochgobernitz em Perturbação, a insistente referência à propriedade pelo nome próprio adensa sua condição espectral na psicologia do narrador, dando-lhe quase a feição de uma entidade.
} 
remoído num discurso que, por vezes, parece não sair do lugar, tal o caráter circular, reiterativo, dos enunciados:

A Gambetti eu disse, não irei a Wolfsegg por um bom tempo, e agora tenho de regressar de imediato. Não consigo mais botar os olhos em Wolfsegg, disse, não suporto mais as paredes, e as pessoas tampouco como as paredes, e o clima se tornou definitivamente impossível para mim. Não pensara que ele se tornaria impossível para mim tão rápido, disse. Meus pais não suporto mais, $\mathrm{e}$ nem a meus irmãos, sobretudo minhas irmãs me dão nos nervos, disse. Estou há muito tempo em Roma, no exterior em geral, tornei-me um estrangeiro, me é insuportável passar uma hora que seja em Wolfsegg sem relutância. Não podia imaginar que voltasse um dia a passar mais tempo em Wolfsegg. Não tenho mais relação alguma com Wolfsegg. Execro tudo o que diga respeito a Wolfsegg. A história de Wolfsegg me pesa de um modo aniquilador, a que não me exporei mais. E agora tenho de regressar de imediato a Wolfsegg. ${ }^{19}$

Como é recorrente na prosa bernhardiana, a técnica discursivonarrativa desse trecho consiste em tecer variações em torno de um motivo-base, com um efeito quase hipnótico. Para além dos recursos estilísticos, porém, o talento do escritor austríaco consiste em dar um solo consistente para algo que, de outro modo, passaria por um conjunto de excreções emocionais do narrador, por uma exaustiva recusa de tudo o que o senso humanístico e as convenções sociais demandam dele em respeito aos mortos, em prol de uma demanda íntima que, de tão afeita, no fim das contas, ao que rejeita, não raro se apresenta como expressão de uma injustiça extrema.

De fato, os requintes de crueldade e a mesquinhez com que Murau julga as ações e disseca o caráter dos familiares - não só os mortos como os vivos, principalmente as irmãs -, como quando analisa suas poses, expressões e vestuários em fotografias onde eles figurariam de forma ridícula, para em seguida fazer uma longa e algo delirante invectiva contra a própria fotografia, acusando-a de ser "a mais abjeta de todas as artes", à qual se deve "a definitiva deformação da natureza e do ser humano que

${ }^{19}$ BERNHARD. Extinção: Uma derrocada, p. 81, grifos do autor. 
nela vive"; ${ }^{20}$ tudo isso, dizíamos, parece testemunhar não apenas contra a sanidade como contra qualquer senso de justiça do personagem.

No entanto, a radicalidade da prosa de Bernhard passa pela composição de um pano de fundo "factual" capaz de tornar a discursividade patológica de seu narrador-protagonista, quando menos, compreensível. É somente numa altura avançada da narrativa que sabemos, por exemplo, a que ponto chegaram as relações dos Murau com o nazismo: nos anos que se seguiram à derrota do Eixo, Wolfsegg serviu de esconderijo para pelo menos dois ex-líderes regionais hitleristas - que retornarão, no enterro, ao lado de vários ex-SS -, acolhendo-os em sua "vila das crianças", lugar com o qual o narrador estabelecia uma estreita relação afetiva na infância. ${ }^{21}$ Tanto que a desistência de reformá-la parece marcar uma inflexão rumo à desistência mais ampla do final: deparar-se com o "horror e terror" da ideia que o animava o faz defrontar-se com um "famigerado vazio hiante". 22

Naturalmente, o peso de seu "pesadelo herdado"23 também afeta Murau enquanto herdeiro material de Wolfsegg. Na segunda parte do livro, que tem como principal cenário o velório na propriedade, o personagem se investe de tais prepotência e pendores autoritários - por exemplo, ao planejar o expurgo da irmã Caecilia e do cunhado - que nada deixam a dever à sua própria imagem da figura paterna. Esta, aliás, se configura no âmbito de uma relação edipiana particularmente complexa, marcada não só pelo rancor como pelo escárnio diante da suposta estultice do genitor. Isso inclui uma ambígua admiração, próxima da devoção, senão do desejo, pelo arcebispo e diplomata romano Spadolini, suposto amante de sua mãe, com a suposta conivência do marido. ${ }^{24}$

${ }^{20}$ BERNHARD. Extinção: Uma derrocada, p. 327.

${ }^{21}$ BERNHARD. Extinção: Uma derrocada, p. 23.

${ }^{22}$ BERNHARD. Extinção: Uma derrocada, p. 439-440, grifo do autor. A expressão "vazio hiante", sempre grifada pelo autor, comparece nada menos que quatorze vezes no episódio.

${ }^{23}$ BERNHARD. Extinção: Uma derrocada, p. 354; grifo do autor.

${ }^{24}$ Também nas narrativas de Günter Grass, inclusive nas que discutimos, é recorrente a traição conjugal ou suposta leviandade sexual por parte das figuras femininas centrais, uma convergência que talvez indique um sentido alegórico relacionado aos temas políticos. Em todo caso, também nesse ponto avultam as diferenças: enquanto no escritor alemão essas situações recebem um tratamento ligeiro, no austríaco elas se prestam a um ágon psicológico entranhado. 
Durante o velório, Spadolini é um dos poucos visitantes convidados a pernoitar na casa principal, sendo-lhe concedido nada menos que o quarto do patriarca morto. Ao esperá-lo na biblioteca, Murau dá uma mostra de sua ambígua relação com o clérigo: "Então ouvi que ele tomava uma ducha, pois a biblioteca confina com o quarto de meu pai, imaginei-o, Spadolini, sob o jato d'água, Spadolini o hedonista, conheço apenas Spadolini o hedonista, pensei.'

Para além do alcance afectual dessas palavras, é oportuno contrastar a situação que elas sugerem, de um conluio íntimo imaginário do narrador com o suposto amante da mãe, com o Hamlet de Shakespeare, de onde Derrida extrai os principais motivos de sua reflexão sobre o espectro, e cujo entrecho se funda justamente na injunção de vingança e/ou justiça do fantasma do rei, não só por seu assassinato como pelo roubo de seu trono e sua esposa por outrem (um irmão traiçoeiro, mas, como veremos, há uma figura semelhante em Extinção); injunção essa que move o príncipe em sua descontrolada e irrefreável ação trágica. Algo desse irrefreável está presente no romance de Bernhard, mas o que quer que configure as injunções paternas comporta, desde sempre, a própria injunção de sua recusa, tão mais forte quanto, a rigor, irrealizável, ao menos plenamente.

Daí, talvez, Murau ocupar ele próprio a posição de um espectro a assombrar seu presente-passado vivo-morto, reivindicando para si um dos atributos que Derrida aponta no fantasma do rei, a partir do elmo com viseira que ele usa: a propriedade de ver sem ser visto. ${ }^{26}$ " $\mathrm{O}$ contemplar ou observar, quando o contemplado ou observado não sabe que é contemplado ou observado", escreve Murau, vangloriando-se dessa habilidade, "é um dos maiores prazeres". ${ }^{27}$ E ele não cessará de dar mostras de um voyeurismo mórbido, como quando se deleita com as fotos e descrições nauseantes do acidente nos jornais, e ainda quando as mostra a seu cunhado, fruindo sua suposta sordidez durante a leitura e comparando-a com sua própria. ${ }^{28}$

\footnotetext{
${ }^{25}$ BERNHARD. Extinção: Uma derrocada, p. 397.

${ }^{26}$ DERRIDA. Espectros de Marx: o estado da dívida, o trabalho do luto e a nova Internacional, p. 23-24.

${ }^{27}$ BERNHARD. Extinção: Uma derrocada, p. 296-299.

${ }^{28}$ BERNHARD. Extinção: Uma derrocada, p. 344-353.
} 
Em outra cena bizarra, ao se deparar com o caixão da mãe fechado, e mesmo se dando conta de que isso se devia ao estado do corpo, Murau não resiste ao impulso de tentar forçar sua abertura. Como num pesadelo recorrente, essa cena grotesca, marcada por um acento cômico-dramático, realiza-se não uma, mas duas vezes, a primeira diante das irmãs, que a fitam perplexas, e a segunda - quando ele já não se importa com os olhares - diante dos caçadores que velavam os corpos. ${ }^{29}$

Um dos raros momentos em que a suposta impiedade do narrador deixa entrever sua grande fissura - o fato de ser movida, também, por uma tortuosa e como que impossível demanda de piedade - é na passagem do esquife do irmão rumo ao túmulo, quando ele sente os joelhos tremerem. ${ }^{30}$ Ainda assim, é um detalhe importante o bastante para reconhecer e enfatizar esse dado, a rigor onipresente na narrativa. No mais, como vimos, o voyeurismo espectral do narrador está permanentemente sujeito à desconstrução, por suas próprias elucubrações ou por outros olhares.

Dos caçadores de Wolfsegg à "tia do Titisee" que Murau evita com asco e pela qual se sente "observado de maneira sórdida", ${ }^{31}$ uma pequena e dispersa comunidade de espectros o cerca com uma mesma demanda básica, de respeito e obediência a um passado ainda presente que lhe repugna enormemente. Dentre os raros contrapontos benfazejos, vale citar os jardineiros da propriedade, a quem o narrador se sente ligado desde a infância, e o minerador judeu Schermaier, sobrevivente de um campo de concentração ao qual fora enviado devido à delação do melhor amigo. É ao lembrar-se dele que Murau esquece a "ideia monstruosa" de fazer com que se abra o caixão da mãe. ${ }^{32}$

Mas há aqueles, também, que se afinam com Murau em sua negação, dentre os quais avulta a figura de seu falecido tio George. Esse personagem, pode-se dizer, é o grande inspirador da revolta e do autoexílio do protagonista: o parente culto, sensível e avesso a Wolfsegg cujas raras visitas o pequeno Franz-Joseph aguardava como um alento único, e cujos gostos e opiniões ele assimilou profundamente. Mais ainda, o tio se lançara a um projeto escritural de desforra semelhante ao que ele se

\footnotetext{
${ }^{29}$ BERNHARD. Extinção: Uma derrocada, p. 332 e 433.

${ }^{30}$ BERNHARD. Extinção: Uma derrocada, p. 467.

${ }^{31}$ BERNHARD. Extinção: Uma derrocada, p. 394.

${ }^{32}$ BERNHARD. Extinção: Uma derrocada, p. 336.
} 
lança agora: uma "antiautobiografia" 33 cujo sumiço e provável destruição o sobrinho cogita se não se deve à mãe. Se Murau está fadado a ser um herdeiro involuntário das riquezas e misérias de Wolfsegg, é a herança espiritual do tio que ele reivindica para si. George, nesse sentido, alinha com Spadolini enquanto deslocamento e recusa anti-hamletiana da figura paterna, complementando suas feições com as de um irmão usurpador.

Uma figura mais episódica, e nisso igualmente fantasmal, é a poetisa Maria, que Murau reverencia e que certa vez o definira como "alguém que extingue", inspirando o título do projeto que, sem saber, ele leva a cabo no instante em que escreve: "tentarei com ele extinguir tudo o que me vier à cabeça, tudo o que estiver escrito nessa Extinção será extinto, disse comigo." 34

$\mathrm{Na}$ impossibilidade de extinção real desse mundo sem conserto - Wolfsegg ou, quiçá, o mundo inteiro visto por olhos gerados em Wolfsegg -, um mundo que, no julgamento inapelável do narrador, nem o sacrifício de uma família real inteira poderia redimir, Murau realiza a extinção de Wolfsegg enquanto propriedade dos seus, num gesto que clama pela remissão de uma culpa que ele sabe e sente profundamente como irremissível; um gesto incapaz, em todo caso, de livrá-lo de seu ato ulterior. Pois nas últimas linhas do romance sabemos que ele decidira, à revelia das irmãs,

[...] oferecer toda Wolfsegg, tal como ela se encontra, e tudo o que a ela pertence, como uma doação totalmente incondicional, à Comunidade Israelita de Viena. Já dois dias depois do enterro tive essa conversa com Eisenberg, meu irmão espiritual, e Eisenberg, em nome da Comunidade Israelita, aceitou minha doação. ${ }^{35}$

Assim como sabemos de sua provável autoextinção, ou seja, seu suicídio, conforme a sugestão deixada pela espectral "voz off" do sobrenarrador bernhardiano ao registrar sua morte precoce. ${ }^{36}$ Mas é digno de nota que esse ato extremo se faça anteceder da invocação de um vínculo fraterno, aliás, de um parentesco, ainda que espiritual, que

\footnotetext{
${ }^{33}$ BERNHARD. Extinção: Uma derrocada, p. 140.

${ }^{34}$ BERNHARD. Extinção: Uma derrocada, p. 397-398.

${ }^{35}$ BERNHARD. Extinção: Uma derrocada, p. 476.

${ }^{36}$ BERNHARD. Extinção: Uma derrocada, p. 476.
} 
sugere uma demanda de pertencimento, e justamente à comunidade dos viventes, sobreviventes, não-sobreviventes e futuros viventes com os quais o herdeiro de Wolfsegg se sente em dívida.

Obviamente, essa quase-autoconcessão aproxima a narrativa de Bernhard/Murau da de Grass/Paul/o Velho em sua dimensão, digamos, apelativa, no sentido de um apelo aos gestos possíveis: o ethos conciliatório que em Passo de caranguejo ganha figuração trágica, mas ainda assim pedagógica, no jovem Wolfgang Stremplin/David Frankfurter. Nesse sentido, do ponto de vista da negatividade extrema de Extinção, talvez a doação de Murau possa ser vista como uma concessão ou suspensão da radicalidade ético-estética em prol de alguma esperança. No entanto, o quase-excesso da quase-autoinclusão no mundo da alteridade judaica traduz a força de uma demanda trágica. Há, além disso, a ambiguidade que se plasma na dura indiferença pela sorte das irmãs. Como é de regra na obra de Bernhard, as ambiguidades sempre emergem.

Mas tentemos, à guisa de conclusão, um cotejo mais sistemático, ainda que breve, das questões de fundo que nos interessam nas duas obras.

\section{Conclusão}

Numa visão panorâmica, as diferenças entre os romances de Grass e Bernhard que sobressaem são as estilísticas, que, no entanto, também se relacionam aos sentidos de seus projetos ético-estéticos. Podemos, aqui, nos valer da conhecida distinção nietzscheana em sua obra sobre a origem da tragédia. ${ }^{37}$

Em Passo de caranguejo, a escrita sóbria, a exposição distanciada e o desenrolar comedido dos fatos configuram algo próximo de uma estética apolínea, ainda que de um apolíneo experimental e cindido. Em Extinção, a escrita torrencial, a exposição intensamente emotiva e a quase dissolução do enredo nela configuram algo mais próximo de uma estética dionisíaca, decerto que fortemente intelectualizada, mas ainda assim votada a uma árdua finalidade catártica.

Se o drama de Paul Pokriefke e seus entornos espectrais culmina num lamento retórico que, no fundo, convoca o futuro a desmenti-lo, a valer-se da razão para dar um fim, sim, ao círculo vicioso do fanatismo e da intolerância, o de Murau se consuma no súbito defrontamento de nossa

\footnotetext{
${ }^{37}$ NIETZSCHE. A origem da tragédia.
} 
percepção com o derradeiro e irreparável atestado da condição agônica do personagem, cuja exposição vínhamos acompanhando e absorvendo empaticamente, mas não sem lhe votar certa suspeita de extravagância ou afetação. É o impacto dessa simultânea reiteração-revelação que confere uma força comovente e catártica ao fim do livro.

De um modo geral, a espectropoética de Bernhard mobiliza recursos formais e figurativos de forma sensivelmente mais consciente e radical que a de Grass. Mas isso não significa que um ethos altaneiro se sobreponha às tensões e contradições encenadas no romance, quando, pelo contrário, o corte autor/narrador-personagem é problematizado na raiz. E justamente aí a estética do excesso de Bernhard talvez revele um impasse ético não muito diverso do que se pode reconhecer na estética desviante de Grass.

Se em Passo de caranguejo a intenção pedagógica revela-se problemática na articulação com um jogo de esquivas e silenciamentos estratégicos cuja estrutura guarda evidente similaridade com outro, nãofictício e ainda mais problemático, o fecho de Extinção pode ser visto como um gesto autopunitivo, como, no fim das contas, um esquivo pedido de perdão por não poder deixar de destilar e partilhar conosco - num discurso que, afinal, não deixa de emular o sensacionalismo midiáticoprovinciano que rejeita - o veneno que lhe foi incutido. Um gesto, também nesse caso, antes do autor-narrador que do narrador-personagem.

Mas os julgamentos, como os espectros, podem proliferar ao infinito, o que significa que outros espectros falam através deles. Darlhes livre vazão significaria tolher o zelo crítico por aqueles que nos falaram no próprio exercício crítico, tanto mais quando entre eles e/ou por meio deles soam vozes-alteridades que, a contrapelo de outras ou de si mesmas, decidiram não calar.

\section{Referências}

BERNHARD, Thomas. Extinção: uma derrocada. Tradução de José Marcos Mariani de Macedo. São Paulo: Companhia das Letras, 2000.

BERNHARD, Thomas. Origem. Tradução de Sergio Tellaroli. São Paulo: Companhia das Letras, 2006.

BERNHARD, Thomas. Perturbação. Tradução de Hans Peter Welper e José Laurenio de Melo. Rio de Janeiro: Rocco, 1999. 
COETZEE, J. M. Günter Grass e o Wilhelm Gustloff. In: COETZEE, J. M. Mecanismos internos: ensaios sobre literatura (2000-2005). Tradução de Sergio Flaksman. São Paulo: Companhia das Letras, 2011. p. 165-179. DÁVALOS, Patricia Miranda. Ficção e autobiografia: uma análise comparativa das narrativas de Thomas Bernhard. 2009. Dissertação (Mestrado em Língua e Literatura Alemã) - Faculdade de Filosofia, Letras e Ciências Humanas, Universidade de São Paulo, São Paulo, 2009.

DERRIDA, Jacques. Espectros de Marx: o estado da dívida, o trabalho do luto e a nova Internacional. Tradução de Anamaria Skinner. Rio de Janeiro: Relume-Dumará, 1994.

GRASS, Günter. Im Krebsgang: Eine Novelle. Göttingen: Steidl, 2002.

GRASS, Günter. Nas peles da cebola. Tradução de Marcelo Backes. Rio de Janeiro: Record, 2007.

GRASS, Günter. O tambor. Tradução de Lúcio Alves e Raquel Valença. Círculo do Livro: São Paulo, 1987.

GRASS, Günter. Passo de caranguejo. Tradução de Flávio Quintiliano. Rio de Janeiro: Nova Fronteira, 2002.

MAZZARI, Marcus Vinnicius. Romance de formação em perspectiva histórica: O tambor de lata de Günther Grass. São Paulo: Ateliê Editorial, 1999.

NIETZSCHE, Friedrich. A origem da tragédia. Tradução de Peter Klaus Ivanov. São Paulo: Centauro, 2008.

PAZ, Ravel Giordano. A invocação dos rancores: alieni(ili)smo e (in) transcendência na Perturbação de Thomas Bernhard. Boletim de Pesquisa NELIC, Florianópolis, v. 12, n. 17, p. 64-84, 2002. Doi: https:// doi.org/10.5007/1984-784X.2012v12n17p64.

Recebido em: 29 de abril de 2019. Aprovado em: 28 de agosto de 2019. 